\title{
Impact of transparent tray-based application of bioactive glasses desensitizer on the permeability of enamel and dentin to hydrogen peroxide: an in vitro study
}

\author{
Qian $\mathrm{Ma}^{1}$, Jingwen Chen ${ }^{2}$, Xiao $\mathrm{Xu}^{2}$ and Tianda Wang ${ }^{1 *}$
}

\begin{abstract}
Background: To investigate the effect of transparent tray-based application of bioactive glasses (BGs) desensitizer on the permeability of enamel and dentin to hydrogen peroxide $\left(\mathrm{H}_{2} \mathrm{O}_{2}\right)$.

Methods: Freshly extracted human first premolars were divided into 6 groups $(n=8)$. Group A and B: without pretreatments; Group C and E: treated with BGs desensitizer only; Group D and F: treated with BGs desensitizer dispensed with a transparent tray. After roots and pulp tissues of the treated tooth specimens were thoroughly removed, acetate buffer was added into pulp chambers and the treated specimens were immersed in distilled water (Groups A, E, and F) or 30\% $\mathrm{H}_{2} \mathrm{O}_{2}$ (Groups B, C, and D) for 30 min at $37^{\circ} \mathrm{C}$. The amount of $\mathrm{H}_{2} \mathrm{O}_{2}$ in the pulp chamber of each group was measured using ultraviolet-visible spectrophotometry.

Results: In control groups (Group A, E, and F), $\mathrm{H}_{2} \mathrm{O}_{2}$ was not detected. The amount of pulpal $\mathrm{H}_{2} \mathrm{O}_{2}$ in Group B, C, and $D$ were $21.149 \pm 0.489 \mu \mathrm{g}, 9.813 \pm 0.426 \mu \mathrm{g}$, and $4.065 \pm 0.268 \mu \mathrm{g}$ respectively. One-way ANOVA analysis indicated that significant differences existed in these groups $(F=459.748, p<0.05)$.

Conclusions: The effect of BGs desensitizer in reducing the permeability of enamel and dentin to $\mathrm{H}_{2} \mathrm{O}_{2}$ could be enhanced when dispensed with a transparent tray.
\end{abstract}

Keywords: Bioactive glasses, Dentin hypersensitivity, Permeability, Tooth bleaching, Transparent tray

\section{Background}

Tooth whitening is any process that lightens the color of teeth. Whitening could be achieved either by physically removing discolored dental hard tissues or chemically bleaching stains. Compared with resin or ceramic veneers and all-ceramic crowns which could physically replace discolored hard tissues, chemically tooth bleaching is considered to be the simplest, most cost-effective and

\footnotetext{
* Correspondence: kqwangtd@gmail.com

'Jiangsu Key Laboratory of Oral Diseases, Nanjing Medical University; Department of General Dentistry, The Affiliated Stomatological Hospital of Nanjing Medical University, Nanjing Medical University, Nanjing 210029, Jiangsu, China

Full list of author information is available at the end of the article
}

least invasive method of treating colored teeth [1-4]. Therefore, it is now widely applied.

The active ingredient in most tooth bleaching products is peroxide in the form of hydrogen peroxide $\left(\mathrm{H}_{2} \mathrm{O}_{2}\right)$ or carbamide peroxide. For example, in-office used bleaching products are highly concentrated $(35 \%$ or 40\%) $\mathrm{H}_{2} \mathrm{O}_{2}$ solutions or bleaching gels containing 5.9\% of $\mathrm{H}_{2} \mathrm{O}_{2}$. Over-the-counter products are usually liquid gels containing a low concentration (10\%) of $\mathrm{H}_{2} \mathrm{O}_{2}[1,3$, 4]. Peroxides are highly reactive and could convert to superoxide $\left(\mathrm{O}^{2-}\right)$, hydroxyl (HO-), peroxyl (ROO-) or alkoxyl (RO-) radicals in physical environments. These oxidative oxygen species can freely penetrate dental 
enamel, react with discolored substances and exert their bleaching or whitening effect. However, side effects like pulp damage would occur when $\mathrm{H}_{2} \mathrm{O}_{2}$ and oxygen species are present at high concentrations or when oral tissues are exposed to them for a long period of time [5]. $\mathrm{H}_{2} \mathrm{O}_{2}$ penetrates dentinal tubules and damages the pulp based on its low molecular weight and the ability to induce protein denaturation [6]. Similarly, the presence of reactive oxygen species in the process of tooth bleaching can lead to temporary inflammations of the pulp and even irreversible changes [7-11].

Since $\mathrm{H}_{2} \mathrm{O}_{2}$ and other reactive oxygen species come into contact with the pulp after penetrating dentinal tubules, attempts to occlude dentinal tubules prior to the application of tooth bleaching products might prevent post-treatment complications from occurring. Hydroxyapatite, the main component of dental hard tissues, is considered as the most ideal material for occluding dentinal tubules. As have been demonstrated in other studies, dentin desensitizers containing bioactive glasses (BGs) could release calcium and phosphorus ions in physiological environments and induce the formation of hydroxyapatite deposit within dentinal tubules [12-14], which could prevent $\mathrm{H}_{2} \mathrm{O}_{2}$ and other reactive oxygen species from penetrating dentinal tubules and reaching the pulp. Hydroxyapatite is considered to have the potential to restore enamel surface, which might also keep the reactive bleaching oxygen species from penetrating the enamel [6]. Moreover, nanoscaled hydroxyapatite contained in a desensitizing paste was demonstrated not to jeopardize its whitening effect [15]. Thus, the application of dentin desensitizers containing BGs prior to tooth bleaching is an ideal method for dealing with postbleaching complications. However, most dentin desensitizers are administrated by simply smearing on teeth. Due to poor patient compliance and short exposure times, their dentinal tubule occluding effects are limited. Therefore, it is expected that a method capable of improving the dentinal tubule occluding effect of dentin desensitizing agents, particularly before the application of dental bleaching products, can be developed.

The aim of this in vitro study is to investigate the impact of BGs desensitizer on the permeability of enamel and dentin to $\mathrm{H}_{2} \mathrm{O}_{2}$. In the present study, BGs desensitizer was dispensed onto tooth specimens with custom made transparent trays which were commonly used clinically as orthodontic retainers or tooth whitening products containers. Transparent trays here were used in order to obtain enough contact time and an effective concentration of the BGs desensitizer. The null hypotheses were (1) BGs desensitizer had no significant effect on the permeability of dentin and enamel to $\mathrm{H}_{2} \mathrm{O}_{2}$ and (2) customized transparent trays had no significant effect on improving the efficiency of the BGs desensitizer on reducing the amount of $\mathrm{H}_{2} \mathrm{O}_{2}$ infiltrating into pulp chambers.

\section{Methods \\ Tooth preparation}

Forty-eight human first premolars without caries, fractures or restorations were freshly extracted due to orthodontic or periodontic reasons from 18 to 40 years old patients and collected with the written informed consent under a protocol approved by the Ethics Committee of Nanjing Medical University (No. PJ 2017-047-001). The teeth were cleaned thoroughly and stored in $0.1 \%$ thymol aqueous solution at $4{ }^{\circ} \mathrm{C}$ for no more than 1 week prior to use. This research proposal was conducted in full accordance with the World Medical Association Declaration of Helsinki.

\section{Hydrogen peroxide calibration curve}

A $0.5 \mathrm{mg} / \mathrm{mL}$ of leucocrystal violet solution was obtained by dissolving $10 \mathrm{mg}$ of leucocrystal violet (Sigma-Aldrich, St. Louis, MO, USA) in $20 \mathrm{~mL}$ of distilled water (DW). A $1.0 \mathrm{mg} / \mathrm{mL}$ horseradish peroxidase solution was obtained by dissolving $10 \mathrm{mg}$ of horseradish peroxidase (Sigma-Aldrich, St. Louis, MO, USA) in $10 \mathrm{~mL}$ of DW. A series of $\mathrm{H}_{2} \mathrm{O}_{2}$ solutions, the concentrations of which were $0.05 \mu \mathrm{g} / \mathrm{mL}, 0.10 \mu \mathrm{g} / \mathrm{mL}, 0.25 \mu \mathrm{g} / \mathrm{mL}, 0.50 \mu \mathrm{g} / \mathrm{mL}$, $1.0 \mu \mathrm{g} / \mathrm{mL}, 2.5 \mu \mathrm{g} / \mathrm{mL}$, and $5.0 \mu \mathrm{g} / \mathrm{mL}$, were obtained by diluting $30 \% \mathrm{H}_{2} \mathrm{O}_{2}$ stock solution (Fisher Scientific, Pittsburgh, PA, USA) with DW.

To obtain a $\mathrm{H}_{2} \mathrm{O}_{2}$ solution calibration curve, $100 \mu \mathrm{L}$ of $0.5 \mathrm{mg} / \mathrm{mL}$ leucocrystal violet solution and $50 \mu \mathrm{L}$ of 1.0 $\mathrm{mg} / \mathrm{mL}$ horseradish peroxidase solution were added into $100 \mu \mathrm{L}, 50 \mu \mathrm{L}, 20 \mu \mathrm{L}, 10 \mu \mathrm{L}, 5 \mu \mathrm{L}, 2.5 \mu \mathrm{L}$, and $1.25 \mu \mathrm{L}$ of $\mathrm{H}_{2} \mathrm{O}_{2}$ solutions and then diluted to $10 \mathrm{~mL}$ with acetate buffer $(\mathrm{pH}=4.5)$. The concentrations of $\mathrm{H}_{2} \mathrm{O}_{2}$ in these solutions were $5.0 \mu \mathrm{g} / \mathrm{mL}, 2.5 \mu \mathrm{g} / \mathrm{mL}, 1.0 \mu \mathrm{g} / \mathrm{mL}, 0.5 \mu \mathrm{g}$ $/ \mathrm{mL}, 0.25 \mu \mathrm{g} / \mathrm{mL}, 0.1 \mu \mathrm{g} / \mathrm{mL}$, and $0.05 \mu \mathrm{g} / \mathrm{mL}$ respectively. After vibrated for $30 \mathrm{~s}$, these solutions were measured with an Ultraviolet-visible (UV-Vis) spectrophotometer (UV-2600, Shimadzu Co., Kyoto, Japan) at a wavelength of $596 \mathrm{~nm}$ against a reference prepared using the same method but with no hydrogen peroxide. A calibration curve was thus obtained [16].

\section{Transparent tray preparation}

Gapping resin discs with a thickness of $1.5 \mathrm{~mm}$ which could cover the reserved areas on buccal surfaces of tooth specimens were prepared with a light-cured composite resin (LC Block-Out Resin, Ultradent, South Jordan, UT, USA). This kind of light-cured composite resin was chosen because we didn't expect an additional dentinal tubule sealing effect. As the surfaces of the tooth specimens were not acid-etched at all and no adhesive was applied, the resin could be easily removed. 
Therefore, it can hardly lead to a sealing effect. Tooth specimens were embedded with alginate impression material (Jeltrate, Dentsply, Tianjin, China) with the buccal surfaces exposed and the gapping resin discs were placed on buccal reserved areas of tooth specimens (Fig. 1a and b). Transparent trays were then fabricated with $1.0-\mathrm{mm}$ polyvinylacetate plates (Erkoflex, Erkodent Erich Kopp $\mathrm{GmbH}$, Pfalzgrafenweiler, Germany) using a vacuum thermoforming unit (Erkoform-3d, Erkodent Erich Kopp $\mathrm{GmbH}$, Pfalzgrafenweiler, Germany) at $175^{\circ} \mathrm{C}$ on these tooth specimens (Fig. 1c and d).

\section{Experimental procedures}

Tooth specimens were randomly divided into 6 groups and each group contained 8 teeth.

Group A and B: Tooth specimens were cut perpendicularly to the long axis of the teeth $3 \mathrm{~mm}$ apically away from the cementoenamel junction (CEJ) with a diamond bur before roots and pulp tissues were thoroughly removed. These tooth specimens were then rinsed with DW for $30 \mathrm{~s}$ and air-dried for $15 \mathrm{~s}$. For each tooth, the crown surfaces were coated with 2 layers of acidproof varnishes, except a reserved area on the buccal surface 1 $\mathrm{mm}$ away from CEJ (Fig. 2a). After turned upside down with the occlusal surface pointed downwards and $25 \mu \mathrm{L}$ of $2 \mathrm{~mol} / \mathrm{L}$ acetate buffer added into the pulp chamber, the tooth specimens were immersed in DW (Group A) or $30 \% \mathrm{H}_{2} \mathrm{O}_{2}$ solution (Group B) for $30 \mathrm{~min}$ at $37^{\circ} \mathrm{C}$ with the level of the liquid lower than the cut surfaces of the teeth (Fig. 2b).
Group C and E: A reserved area $1 \mathrm{~mm}$ away from CEJ on the buccal surface of each tooth was treated with a BGs desensitizer (DDS ${ }^{\mathrm{min}}$, Datsing Bio-tech Co., Ltd., Beijing, China) for $2 \mathrm{~min}$, twice with an interval of $12 \mathrm{~h}$. The teeth were rinsed with DW for $15 \mathrm{~s}$ after each treatment. After immersed for $24 \mathrm{~h}$ in artificial saliva (AS) which contained $\mathrm{CaCl}_{2}(0.7 \mathrm{mM} / \mathrm{L}), \mathrm{MgCl}_{2} \cdot 6 \mathrm{H}_{2} \mathrm{O}(0.2$ $\mathrm{mM} / \mathrm{L}), \mathrm{KH}_{2} \mathrm{PO}_{4}(4.0 \mathrm{mM} / \mathrm{L}), \mathrm{KCl}(30 \mathrm{mM} / \mathrm{L}), \mathrm{NaN}_{3}$ $(0.3 \mathrm{mM} / \mathrm{L})$ and HEPES buffer $(20 \mathrm{mM} / \mathrm{L})$ [17], the treated buccal surfaces of these tooth specimens were rinsed with DW for $15 \mathrm{~s}$ and the root and pulp tissue of each tooth specimen were removed, followed with DW rinsing for $30 \mathrm{~s}$ and air-dried for $15 \mathrm{~s}$. For each tooth, the crown surfaces were coated with 2 layers of acidproof varnishes, except the treated area on the buccal surface. Tooth specimens were turned upside down and $25 \mu \mathrm{L}$ of $2 \mathrm{~mol} / \mathrm{L}$ acetate buffer was added into each pulp chamber. The tooth specimens were then immersed in DW (Group E) or $30 \% \mathrm{H}_{2} \mathrm{O}_{2}$ solution (Group C) for $30 \mathrm{~min}$ at $37^{\circ} \mathrm{C}$ with the liquid level lower than the cut surfaces.

Group D and F: A reserved area $1 \mathrm{~mm}$ away from CEJ on the buccal surface of each tooth was treated with a BGs desensitizer (DDS ${ }^{\mathrm{nx}}$, Datsing Bio-tech Co., Ltd., Beijing, China) dispensed in a transparent tray for $1 \mathrm{~h}$ and rinsed with DW for $15 \mathrm{~s}$. After immersed in AS for $24 \mathrm{~h}$, the treated buccal surfaces of the tooth specimens were rinsed with DW for $15 \mathrm{~s}$. Then, the root and pulp tissue of each tooth were thoroughly removed, and the pulp chamber was rinsed with DW for $30 \mathrm{~s}$ and air-dried for $15 \mathrm{~s}$. For each tooth, the crown surfaces were coated with 2 layers of acidproof varnishes, except the treated
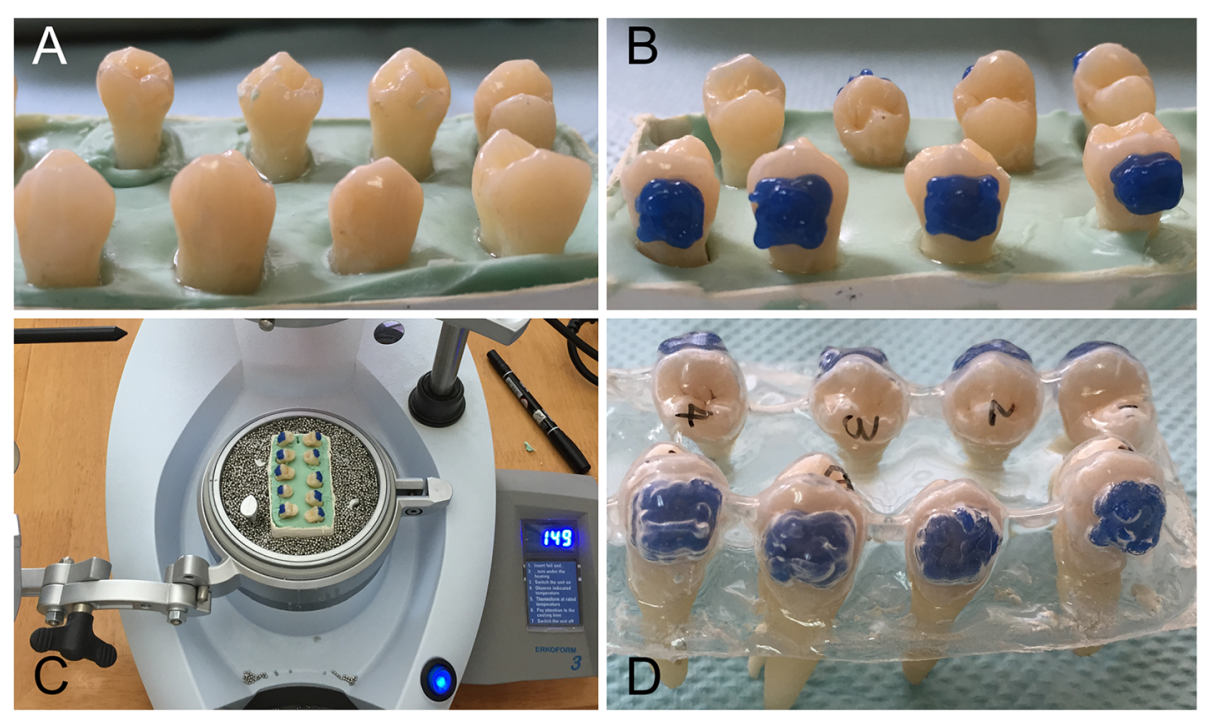

Fig. 1 The preparation of customized transparent tray. a: Tooth specimens were embedded with alginate impression material with the buccal surfaces exposed; $\mathbf{b}$ : Gapping discs which were made of light-cured composite resin were placed on buccal reserved areas of the embedded tooth specimens; $\mathbf{c}$ and $\mathbf{d}$ : Transparent tray was fabricated with polyvinylacetate plates by a vacuum thermoforming unit at $175^{\circ} \mathrm{C}$ on the embedded tooth specimens 

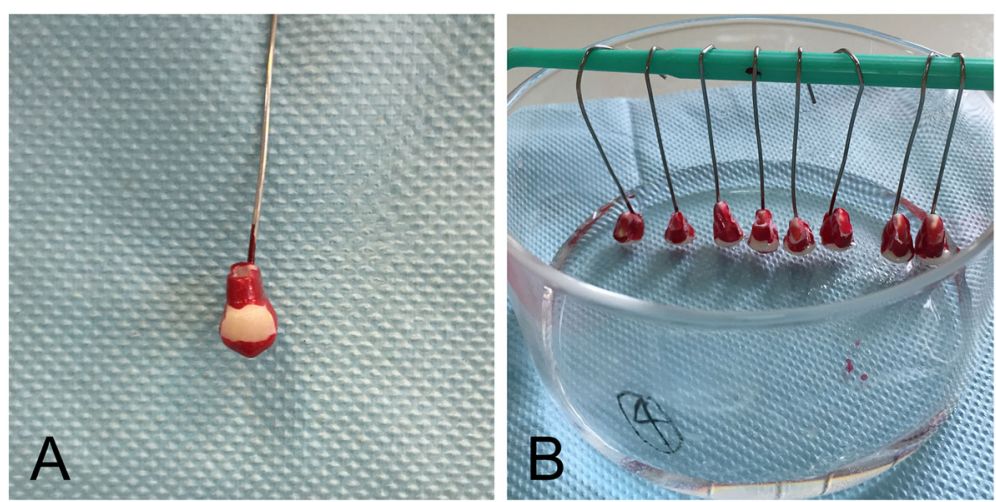

Fig. 2 The treatment of tooth specimens in Group A and Group B. a: The crown surfaces of experimental tooth specimens were coated with 2 layers of acidproof varnishes, except a reserved area on buccal surface $1 \mathrm{~mm}$ away from CEJ; b: After turned upside down with the occlusal surface pointed downwards and $25 \mu \mathrm{L}$ of $2 \mathrm{~mol} / \mathrm{L}$ acetate buffer added into the pulp chamber, the tooth specimens were immersed in DW or $30 \% \mathrm{H}_{2} \mathrm{O}_{2}$ solution for $30 \mathrm{~min}$ at $37^{\circ} \mathrm{C}$ with the level of the liquid lower than the cut surfaces of the teeth

buccal area. Tooth specimens were turned upside down and $25 \mu \mathrm{L}$ of $2 \mathrm{~mol} / \mathrm{L}$ acetate buffer was added into each pulp chamber. The tooth specimens were then immersed in DW (Group F) or $30 \% \mathrm{H}_{2} \mathrm{O}_{2}$ solution (Group D) for $30 \mathrm{~min}$ at $37^{\circ} \mathrm{C}$ with the liquid level lower than the cut surfaces.

After treatments mentioned above, acetate buffer in pulp chamber of each treated tooth was transferred into glass tubes labeled as Groups A to F. The pulp chamber of each tooth was rinsed twice with $100 \mu \mathrm{L}$ of DW which was then transferred to the corresponding glass tubes. One hundred microliters of leucocrystal violet solution $(5 \mathrm{mg} / \mathrm{mL})$ and $50 \mu \mathrm{L}$ of horseradish peroxidase solution $(1 \mathrm{mg} / \mathrm{mL})$ were added to each glass tube. After diluted to $10 \mathrm{~mL}$ with acetate buffer $(\mathrm{pH}=4.5)$ and vibrated for $30 \mathrm{~s}$, the liquid in each glass tube was measured with UV-Vis spectrophotometer at the wavelength of $596 \mathrm{~nm}$. The amount of $\mathrm{H}_{2} \mathrm{O}_{2}$ in each sample was calculated using the calibration curve.

\section{Statistical analysis}

Statistical analysis was performed using SPSS 13.0 for Windows (SPSS Inc., Chicago, IL, USA). Differences in the amount of $\mathrm{H}_{2} \mathrm{O}_{2}$ in each group were analyzed using one-way ANOVA analysis. Once overall differences among the means were observed, post hoc tests of LSD (least significant difference) were performed for multiple comparisons. $P$-values less than 0.05 were considered statistically significant.

\section{Results}

As is shown in Table 1, after tooth specimens were immersed in DW for $30 \mathrm{~min}$ at $37^{\circ} \mathrm{C}$, regardless of what kind of surface treatment was applied, hydrogen peroxide was not detected in pulp chambers in control groups (Group A, E, and F). In experimental groups (Group B, $\mathrm{C}$, and $\mathrm{D}$ ), on the other hand, pulpal $\mathrm{H}_{2} \mathrm{O}_{2}$ was found. The amount of pulpal $\mathrm{H}_{2} \mathrm{O}_{2}$ in Group $\mathrm{B}$, Group $\mathrm{C}$, and Group D are shown in Fig. 3. The results one-way ANOVA analysis and LSC post hoc tests indicated that significant differences existed between these groups $(\mathrm{F}=$ $459.748, p<0.05)$.

\section{Discussion}

Peroxides such as hydrogen peroxide and carbamide peroxide used to bleach discolored dental hard tissues have been shown to have the ability to penetrate enamel and dentin, which is determined by several factors including the concentration of peroxides, the exposure time of teeth to peroxides, cracks and restorative

Table 1 The amount of pulpal $\mathrm{H}_{2} \mathrm{O}_{2}$ in each group $(\mu \mathrm{g})$

\begin{tabular}{llll}
\hline Group & N & Treatments & $\mathrm{H}_{2} \mathrm{O}_{2}$ content $(\mu \mathrm{g})^{\mathrm{a}}$ \\
\hline A (Negative control) & 8 & No surface treatment, immersed in DW & 0.0 \\
B (Positive control) & 8 & No surface treatment, immersed in $30 \% \mathrm{H}_{2} \mathrm{O}_{2}$ & $21.149 \pm 0.489$ \\
C & 8 & Surface treated with BGs desensitizer only, immersed in $30 \% \mathrm{H}_{2} \mathrm{O}_{2}$ & $9.813 \pm 0.426$ \\
D & 8 & Surface treated with BGs desensitizer and transparent tray, immersed in $30 \% \mathrm{H}_{2} \mathrm{O}_{2}$ & $4.065 \pm 0.268$ \\
E & 8 & Surface treated with BGs desensitizer only, immersed in DW & 0.0 \\
F & 8 & Surface treated with BGs desensitizer and transparent tray, immersed in DW & 0.0 \\
\hline
\end{tabular}

a Values are means \pm standard deviations 


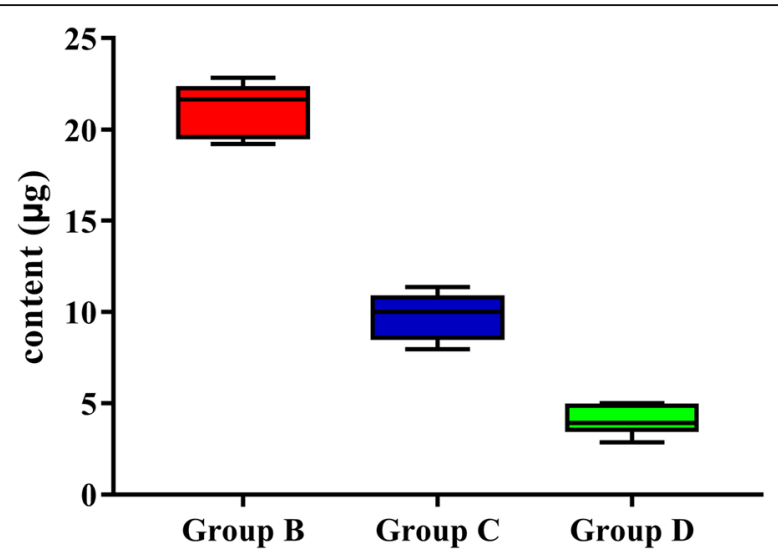

Fig. 3 The amount of pulpal $\mathrm{H}_{2} \mathrm{O}_{2}$ in Group B, Group C, and Group D. After tooth specimens were immersed in $30 \% \mathrm{H}_{2} \mathrm{O}_{2}$ for 30 min at $37^{\circ} \mathrm{C}, 21.149 \pm 0.489 \mu \mathrm{g}, 9.813 \pm 0.426 \mu \mathrm{g}$ and $4.065 \pm 0.268 \mu \mathrm{g}$ of pulpal $\mathrm{H}_{2} \mathrm{O}_{2}$ was detected in Group B, Group C, and Group $D$, respectively

materials existing on teeth, and etc. [18-23]. As was shown in previous studies, more than $66 \%$ of patients suffered from dentin hypersensitivity or gingival irritation after tooth bleaching [9]. Other studies have also reported that the infiltration of peroxides into the pulp could lead to pulpal inflammation and necrosis [24, 25]. Although at present, no literature has given the concentration of $\mathrm{H}_{2} \mathrm{O}_{2}$ in the pulp that can lead to dentin hypersensitivity of post-bleaching pain of patients, in a study using bovine teeth, bleaching agents using $\mathrm{H}_{2} \mathrm{O}_{2}$, the concentrations of which were 20 and $35 \%$, as their main components were shown to lead to moderate or severe inflammation in the upper thirds of the coronal pulp. The authors concluded that in-office bleaching protocols using lower concentrations of $\mathrm{H}_{2} \mathrm{O}_{2}$ should be preferred [26]. Since tooth bleaching agents are thought to infiltrate into the pulp through dentinal tubules, the application of dentin desensitizers which could occlude dentinal tubules is, therefore, an effective option to help dentists deal with dentin hypersensitivity and pulpal damage emerging during or after tooth bleaching [2729]. Dentin desensitizers containing potassium nitrate or sodium fluoride are widely used to solve dentin hypersensitivity, especially before or after tooth bleaching. They are also added into bleaching agents to alleviate pulpal responses without jeopardizing the tooth bleaching effect. However, desensitizing agents which contain potassium nitrate relief pulpal symptoms primarily by reducing the activity of dentinal sensory nerves, which is the main effect of potassium ions [30]. As a result, they cannot help us prevent the infiltration of peroxides into pulp tissues from occurring or reduce the amount of pulpal peroxides. Thus, they are not ideal for us to solve post-bleaching pulpal damage. Sodium fluoride, on the other hand, alleviates dentin hypersensitivity by inducing a calcium fluoride layer which covers enamel and exposed dentin [30]. However, as this layer could be easily removed by tooth brushing, the utilization of sodium fluoride is limited. Therefore, it is urgent that better products or methods be developed.

Bioactive glasses (BGs), the main component of which is $\mathrm{CaO}-\mathrm{Na}_{2} \mathrm{O}-\mathrm{P}_{2} \mathrm{O}_{5}-\mathrm{SiO}_{2}$, were developed in Professor Hench's laboratory at the University of Florida in 1969 and were later known as $45 \mathrm{~S} 5$ or Bioglass ${ }^{\circ}$ [31]. Due to the ability in inducing the formation of hydroxycarbonate apatite (HCA) in physiological conditions, BGs are comprehensively studied in the fields of tissue engineering, bone regeneration and dentin remineralization [3133]. BGs have been demonstrated to occlude dentinal tubules by inducing hierarchical mineralization via the precipitation of apatite composed of calciumsilicate in dentinal tubules [34]. Our previous study showed that dentinal tubules, which were in tooth specimens treated twice a day with BGs desensitizing paste and immersed in artificial saliva for 7 days, could be completely occluded with calcium-deficient hydroxyapatite deposits to a depth of 5.5-8.1 $\mu \mathrm{m}$ [14]. Therefore, BGs desensitizers would be ideal to alleviate dentin hypersensitivity, especially when it happens during or after the process of tooth bleaching.

Although BGs desensitizer is considered to be an ideal material to treat dentin hypersensitivity, in clinical practice, most dentin desensitizers including BGs desensitizing paste are administrated by patients themselves according to the manufacturer's instructions after the first application carried out by dental practitioners. Poor patient compliance and short therapeutic exposure will lead to relatively limited dentinal desensitization and dentinal tubule occlusion effects. In order to deal with this condition, a transparent tray which could hold the desensitizer for a while in patients' oral cavities is considered. In our previous research, better dentinal tubules occluding effect could be guaranteed by using BGs desensitizer dispensed in a transparent tray [14]. Therefore, a more effective approach to deal with dentin hypersensitivity and pulpal damage during or after tooth bleaching is expected. In the present study, the peroxides penetration-reducing effect of BGs desensitizer in the existence of transparent trays was explored by measuring the amount of pulpal $\mathrm{H}_{2} \mathrm{O}_{2}$ through UV-Vis spectrophotometry after pretreated tooth samples were immersed in $30 \% \mathrm{H}_{2} \mathrm{O}_{2}$.

As is shown in Table 1, no pulpal $\mathrm{H}_{2} \mathrm{O}_{2}$ was detected in teeth in group $\mathrm{A}, \mathrm{E}$, and $\mathrm{F}$. The concentration of pulpal $\mathrm{H}_{2} \mathrm{O}_{2}$ in teeth without BGs desensitizer treatment (group $\mathrm{B}$ ) was the highest among all experimental groups. This fact, which was very similar to that reported by other researchers, indicated that $\mathrm{H}_{2} \mathrm{O}_{2}$ could penetrate enamel and dentin, as was assumed before. 
Concentrations of pulpal $\mathrm{H}_{2} \mathrm{O}_{2}$ in tooth specimens treated with BGs desensitizer, regardless of whether transparent trays were employed or not, were significantly lower than that in untreated tooth specimens, indicating that BGs desensitizer had the ability to keep $\mathrm{H}_{2} \mathrm{O}_{2}$ from infiltrating into pulp chambers. This could attribute to the dentinal tubule occluding effect of HCA deposits which were induced by BGs in artificial saliva. A series of stages were thought to be responsible for HCA formation in physiological fluids including artificial saliva. Firstly, rapid ion exchange happens between $\mathrm{Na}^{+}$ and $\mathrm{Ca}^{2+}$ from $\mathrm{BGs}$ and $\mathrm{H}^{+}$from the solution, leading to the formation of silanol bonds and a silica-rich layer on the surface of BGs. Thereafter, an amorphous calcium phosphate layer on the surface of this silica-rich layer appears by sequestering $\mathrm{Ca}^{2+}$ and phosphorous and further crystallizes into $\mathrm{HCA}$ layers, consuming $\mathrm{OH}^{-}$and $\mathrm{CO}_{3}{ }^{2-}$. HCA layers then combine with each other and with dentinal tubule walls, leading to their dentinal tubule occluding effect [35-37]. HCA layers are also believed to restore cracks within dental enamel.

In this study, transparent trays were demonstrated to help improve the effect of BGs desensitizer as the concentration of pulpal $\mathrm{H}_{2} \mathrm{O}_{2}$ was significantly decreased in BGs desensitizer treating groups after transparent trays were employed. Customized trays are widely used as removable retainers in orthodontics and also as agentholding devices using in tooth bleaching [38]. In the latter condition, customized trays have been found to reduce the penetration of peroxide into the pulp chamber [39]. Moreover, clinical trials have demonstrated that the level of sensitivity during the in-office tooth bleaching procedure could be reduced when bleaching agents were covered with customized trays $[40,41]$. Here, customfitted transparent trays were used as the supporter of BGs desensitizer in order to prolong the treatment duration by putting BGs desensitizer into the storage space $[32,42,43]$. By doing so, the dilution of BGs desensitizer by saliva in patients' oral cavities would be decelerated and the exposure duration of tooth to desensitizer would be extended.

\section{Conclusion}

With the limits of this study, the null hypothesis has to be rejected. The additional use of transparent trays, combined with a simple coating of BGs containing dentin desensitizer, could significantly reduce the infiltration of $\mathrm{H}_{2} \mathrm{O}_{2}$ into pulp chambers. In conclusion, application of BGs desensitizer with transparent trays as its container was considered to be more effective in keeping peroxides in tooth bleaching agents from penetrating enamel and dentin and damaging pulp tissues during or after tooth bleaching treatment. This could open up new possible applications in future clinical dentistry.

\section{Abbreviations}

$\mathrm{H}_{2} \mathrm{O}_{2}$ : Hydrogen peroxide; $\mathrm{BGs}$ : Bioactive glasses; DW: Distilled water; UVVis: Ultraviolet-visible; CEJ: Cementoenamel junction; AS: Artificial saliva; HCA: Hydroxycarbonate apatite

\section{Acknowledgements \\ Not applicable.}

\section{Authors' contributions}

Q-M participated in the research design of the study and in the data analysis and wrote the manuscript. JW-C participated in the experimental process and in the design of the study. X-X participated in the experimental process. TD-W participated in the design of the study and reviewed the manuscript. All authors read and approved the final manuscript.

\section{Funding}

This work was supported by the National Natural Science Foundation of China (No. 81701023 and 81801029) and the Priority Academic Program Development of Jiangsu Higher Education Institutions (No. 2018-87). The funders of the study had no role in study design, data collection, data analysis, data interpretation, or writing of the report.

\section{Availability of data and materials}

The data sets used and analyzed during the current study are available from the corresponding author upon reasonable request.

\section{Ethics approval and consent to participate}

This research proposal was conducted in full accordance with the World Medical Association Declaration of Helsinki and has obtained the approval from the Ethics Committee of Nanjing Medical University (No. PJ 2017-047001). Written informed consents were obtained for all participants.

\section{Consent for publication}

Not applicable.

\section{Competing interests}

The authors declare that they have no competing interests.

\section{Author details}

${ }^{1}$ Jiangsu Key Laboratory of Oral Diseases, Nanjing Medical University; Department of General Dentistry, The Affiliated Stomatological Hospital of Nanjing Medical University, Nanjing Medical University, Nanjing 210029, Jiangsu, China. ${ }^{2}$ Stomatological College of Nanjing Medical University, Nanjing Medical University, Nanjing 210029, Jiangsu, China.

Received: 28 December 2018 Accepted: 29 March 2020

Published online: 10 April 2020

\section{References}

1. Joiner A. The bleaching of teeth: a review of the literature. J Dent. 2006;34: 412-9.

2. Palé M, Mayoral JR, Llopis J, Vallès M, Basilio J, Roig M. Evaluation of the effectiveness of an in-office bleaching system and the effect of potassium nitrate as a desensitizing agent. Odontology. 2014;102:203-10.

3. Carey CM. Tooth whitening: what we now know. J Evid Based Dent Pract 2014;14(Suppl):70-6.

4. Joiner A. Whitening toothpastes: a review of the literature. J Dent. 2010; 38(Suppl 2):e17-24.

5. Giniger M, Macdonald J, Ziemba S, Felix H. The clinical performance of professionally dispensed bleaching gel with added amorphous calcium phosphate. J Am Dent Assoc. 2005;136:383-92.

6. Kawamata H, Fujita K, Ishizaki T, Heyman R, Ikemi T. A new enamel restoring agent for use after bleaching. J Dent Re. 2004;83:1919.

7. Trindade FZ, Ribeiro AP, Sacono NT, Oliveira CF, Lessa FC, Hebling J, et al. Trans-enamel and trans-dentinal cytotoxic effects of a $35 \% \mathrm{H}_{2} \mathrm{O}_{2}$ bleaching gel on cultured odontoblast cell lines after consecutive applications. Int Endod J. 2009:42:516-24

8. Reinhardt JW, Eivins SE, Swift EJ Jr, Denehy GE. A clinical study of nightguard vital bleaching. Quintessence Int. 1993;24:379-84. 
9. Haywood VB, Leonard RH, Nelson CF, Brunson WD. Effectiveness, side effects and long-term status of nightguard vital bleaching. J Am Dent Assoc. 1994;125:1219-26.

10. Sterrett J, Price RB, Bankey T. Effects of home bleaching on the tissues of the oral cavity. J Can Dent Assoc. 1995;61:412-7 420.

11. Leonard RH Jr, Haywood VB, Phillips C. Risk factors for developing tooth sensitivity and gingival irritation associated with nightguard vital bleaching. Quintessence Int. 1997;28:527-34.

12. Litkowski LJ, Hack GD, Greenspan DC. Compositions containing bioactive glass and their use in treating tooth hypersensitivity. US Patent. 1998; 5735942.

13. Litkowski LJ, Hack GD, Greenspan DC. Methods of treatment using bioactive glass. US Patent. 2000;6086374.

14. Ma Q, Wang TD, Meng QF, Xu X, Wu HY, Xu DJ, et al. Comparison of in vitro dentinal tubule occluding efficacy of two different methods using a nanoscaled bioactive glass-containing desensitising agent. J Dent. 2017:60:63-9.

15. Browning WD, Cho SD, Deschepper EJ. Effect of a nano-hydroxyapatite paste on bleaching-related tooth sensitivity. J Esthet Restor Dent. 2012;24(4): 268-76

16. Patri G, Acharya G, Agrawal P, Panda V. Spectrophotometric evaluation of the pulpal peroxide levels in intact and restored teeth - an Invitro study. J Clin Diagn Res. 2016;10:ZC44-7.

17. Gandolfi MG, Silvia F, Pashley DH, Gasparotto G, Carlo P. Calcium silicate coating derived from Portland cement as treatment for hypersensitive dentin. J Dent. 2008;36:565-78.

18. McEvoy SA. Chemical agents for removing intrinsic stains from vital teeth. II. Current techniques and their clinical application. Quintessence Int. 1989;20: 379-84

19. Hanks CT, Fat JC, Wataha JC, Corcoran JF. Cytotoxicity and dentin permeability of carbamide peroxide and hydrogen peroxide vital bleaching materials, in vitro. J Dent Res. 1993;72:931-8.

20. Benetti AR, Valera MC, Mancini MN, Miranda CB, Balducci I. In vitro penetration of bleaching agents into the pulp chamber. Int Endod J. 2004 37:120-4.

21. Adibfar A, Steele A, Torneck CD, Titley KC, Ruse D. Leaching of hydrogen peroxide from bleached bovine enamel. J Endod. 1992;18:488-91.

22. Gökay O, Yilmaz F, Akin S, Tunçbilek M, Ertan R. Penetration of the pulp chamber by bleaching agents in teeth restored with various restorative materials. J Endod. 2000;26:92-4.

23. Cooper JS, Bokmeyer TJ, Bowles WH. Penetration of the pulp chamber by carbamide peroxide bleaching agents. J Endod. 1992;18:315-7.

24. Matis BA, Mousa HN, Cochran MA, Eckert GJ. Clinical evaluation of bleaching agents of different concentrations. Quintessence Int. 2000;31:303-10.

25. Leonard RH Jr, Bentley C, Eagle JC, Garland GE, Knight MC, Phillips C. Nightguard vital bleaching: a long-term study on efficacy, shade retention, side effects, and patients' perceptions. J Esthet Restor Dent. 2001;13:357-69.

26. Cintra LT, Benetti F, Ferreira LL, Gomes-Filho JE, Ervolino E, Gallinari Mde O, et al. Penetration capacity, color alteration and biological response of two in-office bleaching protocols. Braz Dent J. 2016;27(2):169-75.

27. Paula E, Kossatz S, Fernandes D, Loguercio A, Reis A. The effect of perioperative ibuprofen use on tooth sensitivity caused by in-office bleaching. Oper Dent. 2013;38:601-8.

28. Charakorn P, Cabanilla LL, Wagner WC, Foong WC, Shaheen J, Pregitzer R, et al. The effect of preoperative ibuprofen on tooth sensitivity caused by inoffice bleaching. Oper Dent. 2009;34:131-5.

29. Bonafé $E$, Loguercio AD, Reis A, Kossatz $\mathrm{S}$. Effectiveness of a desensitizing agent before in-office tooth bleaching in restored teeth. Clin Oral Investig. 2014;18:839-45.

30. Orchardson R, Gillam DG. Managing dentin hypersensitivity. J Am Dent Assoc. 2006;137:990-8.

31. Hench LL, Jones JR. Bioactive glasses: Frontiers and challenges. Front Bioeng Biotechnol. 2015;3:194

32. Du MQ, Bian Z, Jiang H, Greenspan DC, Burwell AK, Zhong J, et al. Clinical evaluation of a dentifrice containing calcium sodium phosphosilicate (novamin) for the treatment of dentin hypersensitivity. Am J Dent. 2008;21: 210-4.

33. Mehta $A B$, Kumari $V$, Jose $R$, Izadikhah V. Remineralization potential of bioactive glass and casein phosphopeptide-amorphous calcium phosphate on initial carious lesion: an in-vitro pH-cycling study. J Conserv Dent. 2014; $17: 3-7$.
34. Wang YN, Gao JX, Jiang T, Liang SS, Zhou Y, Matis BA. Evaluation of the efficacy of potassium nitrate and sodium fluoride as desensitizing agents during tooth bleaching treatment - a systematic review and meta-analysis. J Dent. 2015:43:913-23.

35. Rahaman MN, Day DE, Bal BS, Fu Q, Jung SB, Bonewald LF, et al. Bioactive glass in tissue engineering. Acta Biomater. 2011;7:2355-73.

36. Jones JR. Review of bioactive glass: from Hench to hybrids. Acta Biomater. 2013:9:4457-86

37. Sauro S, Thompson I, Watson TF. Effects of common dental materials used in preventive or operative dentistry on dentin permeability and remineralization. Oper Dent. 2011;36:222-30.

38. De Abreu DR, Sasaki RT, Amaral FL, Flório FM, Basting RT. Effect of homeuse and in-office bleaching agents containing hydrogen peroxide associated with amorphous calcium phosphate on enamel microhardness and surface roughness. J Esthet Restor Dent. 2011;23:158-68.

39. Kwon SR, Wertz PW, Dawson DV, Cobb DS, Denehy G. The relationship of hydrogen peroxide exposure protocol to bleaching efficacy. Oper Dent 2013;38:177-85.

40. Santana MA, Nahsan FP, Oliveira AH, Loguércio AD, Faria-e-Silva AL. Randomized controlled trial of sealed in-office bleaching effectiveness. Braz Dent J. 2014;25:207-11.

41. Correa AC, Santana TR, Nahsan FP, Loguercio AD, Faria-e-Silva AL. The impact of a customized tray on in-office bleaching tooth sensitivity: a randomized clinical trial. Oper Dent. 2016;41:15-22.

42. Burwell AK, Litkowski LJ, Greenspan DC. Calcium sodium phosphosilicate (NovaMin): remineralization potential. Adv Dent Res. 2009:21:35-9.

43. Amaechi BT, Mathews SM, Mensinkai PK. Effect of theobromine-containing toothpaste on dentin tubule occlusion in situ. Clin Oral Investig. 2015;19: 109-16.

\section{Publisher's Note}

Springer Nature remains neutral with regard to jurisdictional claims in published maps and institutional affiliations.
Ready to submit your research? Choose BMC and benefit from:

- fast, convenient online submission

- thorough peer review by experienced researchers in your field

- rapid publication on acceptance

- support for research data, including large and complex data types

- gold Open Access which fosters wider collaboration and increased citations

- maximum visibility for your research: over $100 \mathrm{M}$ website views per year

At $\mathrm{BMC}$, research is always in progress.

Learn more biomedcentral.com/submission 